\title{
Consumer Behaviour towards Consumer Durable Goods in Thiruvarur District
}

\author{
P. Sathya ${ }^{1}$, C. Vijayasanthi ${ }^{2}$ \\ ${ }^{1,2}$ Assistant Professor in Commerce, Sengamala Thayaar Educational Trust Women's College, Mannargudi, TN-India
}

\begin{abstract}
Consumer behavior is centre of the modern marketing, understanding his behaviour is quite essential for efficient and effective marketing management. Customers may state their needs, wants but act otherwise. They may not be in touch with their deeper motivations. India's consumer market is riding the crest of the country's economic boom. Driven by a young population with access to disposable incomes and easy finance options, the consumer market has been throwing up staggering figures. Marketing problem enhancing from the consumers' behaviour has a greater degree of similarity behavioral problems relating to the consumer durables. use of durable goods is becoming increasingly popular in recent years in India. The introduction of different types of durables has also brought out many significant changes in the tastes and preferences of ultimate consumers in recent years.
\end{abstract}

Keywords: Consumer behaviour, Consumer Durables, Influence on buying decision

\section{Introduction}

Buying behaviour has gained increased importance in a consumer oriented marketing planning and management. The buying behaviour of consumer has become a great necessity in modern marketing system, because success or failure ultimately depends upon the buying behaviour of the target customers considered individually or a group. Therefore in order to undertake the marketing programmes among different segment markets, the marketing management must find out the various factors that influences in buying decisions of the consumer. The character, behaviour and attitude of consumer are the important dimensions in the decision making process. It has now become the central topic of modern marketing since the ultimate aim of marketing is consumer satisfaction and profit making.

\section{Meaning}

Consumer behaviour is the study of how individual customers, groups or organizations select, buy, use, and dispose ideas, goods, and services to satisfy their needs and wants. It refers to the actions of the consumers in the marketplace and the underlying motives for those actions.

\section{Definition}

1) According to Engel, Blackwell, and Mansard, 'consumer behaviour is the actions and decision processes of people who purchase goods and services for personal consumption'.

2) According to Louden and Bitta, 'consumer behaviour is the decision process and physical activity, which individuals engage in when evaluating, acquiring, using or disposing of goods and services'.

\section{Characteristics of Buyer Behaviour}

- Buyer behaviour comprise mental and physical activates of a buyer when he wants to buy and service to satisfy his needs.
- It includes both visible and invisible of buyer. The visible activates refer to physical activity like actually going to the market place, buying the product and consuming them. The invisible activates on the other hand, refer to mental activates like thinking about the product, deciding to buy or not to buy that product, to buy one brand instead of another etc.

- Buyer behaviour is very complex and dynamic also.

- It is constantly changing requiring certain adjustment. The marketing management which fails to make such adjustments, would certainly lose its market

- An individual buying behaviour is also influenced by internal factors such as needs, habits, instincts, motives, attitudes etc and also by outside or environmental factors such as family, social, groups, culture, status, positions, economic and business conditions. In narrow sense, consumer behaviour is the act of a consumer when he is engaged in buying and consuming a good or a service

\section{Consumer Durables: Industry Size, Growth and Trends}

During FY07, volume share of the single largest consumer durable was colour TVs at $30 \%$, followed by refrigerators and air conditioners at $18 \%$ and $13 \%$ respectively. Washing machines and other assorted consumer durables captured a share in the total volume by $5 \%$ and $34 \%$ respectively. 


\section{International Journal of Science and Research (IJSR) \\ ISSN (Online): 2319-7064}

Index Copernicus Value (2013): 6.14 | Impact Factor (2015): 6.391

Major Consumer Durables: Volume share

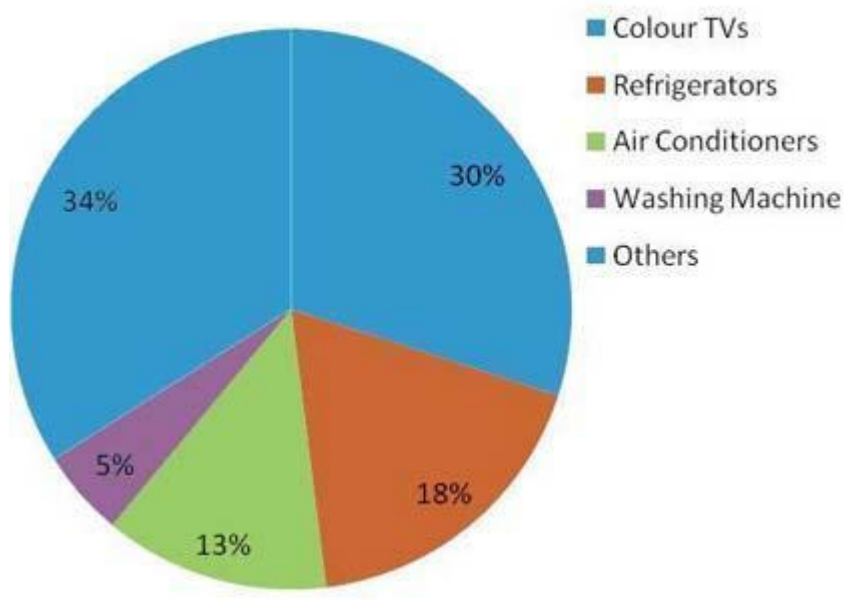

Source : http://info.shine.com/Industry-

Information/Consumer-Durables/902.aspx

The key growth drivers for the Indian consumer durables industry:

- Rise in disposable income: The demand for consumer electronics has been rising with the increase in disposable income coupled with more and more consumers falling under the double income families. The growing Indian middle class is an attraction for companies who are out there to woo them.

- Availability of newer variants of a product: Consumers are spoilt for choice when it comes to choosing products. Newer variants of a product will help a company in getting the attention of consumers who look for innovation in product

- Product pricing: The consumer durables industry is highly price sensitive, making price the determining factor in increasing volumes, at least for lower range consumers. For middle and upper range consumers, it is the brand name, technology and product features that are important.

- Availability of financing schemes: Availability of credit and the structure of the loan determine the affordability of the product. Sale of a particular product is determined by the cost of credit as much as the flexibility of the scheme.

- Rise in the share of organised retail: Rise in organised retail will set the growth pace of the Indian consumer durables industry. According to a working paper released by the Indian Council for Research on International Economic Relations (ICRIER), organised retail which constituted a mere four percent of the retail sector in FY07 is likely to grow at $45-50 \%$ per annum and quadruple its share in the total retail pie $16 \%$ by $2011-$ 2012. The share will grow with bigger players entering the market.

- Innovative advertising and brand promotion: Sales promotion measures such as discounts, free gifts and exchange offers help a company in distinguishing itself from others.

- Festive season sales: Demand for colour TVs usually pick up during the festive seasons. As a result most companies come out with offers during this period to cash in on the festive mood. This period will continue to be the growth driver for consumer durable companies.

\section{A consumer's buyer behaviour is influenced by four major factors:}

1) Cultural,

2) Social

3) Personal

4) Psychological.

Consumer's buyer behaviour and the resulting purchase decision are strongly influenced by cultural, social, personal and psychological characteristics. An understanding of the influence of these factors is essential for marketers in order to develop suitable marketing mixes to appeal to the target customer.

Cultural Factors include a consumer's culture, subculture and social class. These factors are often inherent in our values and decision processes.

Social Factors include groups (reference groups, aspirational groups and member groups), family, roles and status. This explains the outside influences of others on our purchase decisions either directly or indirectly.

Personal factors include such variables as age and lifecycle stage, occupation, economic circumstances, lifestyle (activities, interests, opinions and demographics), personality and self concept. These may explain why our preferences often change as our 'situation' changes.

PSCHOLOGICAL Factors affecting our purchase decision include motivation (Maslow's hierarchy of needs), perception, learning, beliefs and attitudes.

\section{Objectives of the Study}

- To study the buying behaviour for selected consumer durables.

- To identify the factors influencing the consumers in the selection and use of particular products.

\section{Methodology}

The data for the purpose of the present study have been collected through primary and Secondary data.

\section{Primary data}

Primary data has been collected through structured questionnaire from 50 respondents in Thiruvarur District.

\section{Secondary data}

Secondary data include published data such as data from Books, journals, periodicals, brouchers, Reports, etc.

\section{Results and Discussion}




\section{International Journal of Science and Research (IJSR) ISSN (Online): 2319-7064}

Index Copernicus Value (2013): 6.14 | Impact Factor (2015): 6.391

Table 1: Profile of the Respondents

\begin{tabular}{|c|c|c|c|c|}
\hline $\begin{array}{l}\text { S. } \\
\text { No }\end{array}$ & $\begin{array}{c}\text { Demographic } \\
\text { Variables }\end{array}$ & & $\begin{array}{c}\text { No. of } \\
\text { Respondents }\end{array}$ & Percentage \\
\hline \multirow{4}{*}{1} & \multirow{4}{*}{ Age (Years) } & Upto 20 & 8 & 16 \\
\hline & & $21-30$ & 25 & 50 \\
\hline & & $31-40$ & 7 & 14 \\
\hline & & Above 40 & 10 & 20 \\
\hline \multirow{2}{*}{2} & \multirow{2}{*}{ Sex } & Male & 26 & 52 \\
\hline & & Female & 24 & 48 \\
\hline \multirow{5}{*}{3} & \multirow{5}{*}{$\begin{array}{l}\text { Educational } \\
\text { Qualification }\end{array}$} & $\begin{array}{l}\text { No formal } \\
\text { Education }\end{array}$ & 4 & 8 \\
\hline & & Upto H.Sc. & 8 & 16 \\
\hline & & Graduate & 15 & 30 \\
\hline & & Post Graduate & 11 & 22 \\
\hline & & Diploma & 6 & 12 \\
\hline \multirow{4}{*}{4} & \multirow{4}{*}{ Occupation } & Professional & 6 & 12 \\
\hline & & Home Maker & 10 & 20 \\
\hline & & Employees & 17 & 34 \\
\hline & & Professionals & 5 & 10 \\
\hline \multirow{5}{*}{5} & \multirow{5}{*}{$\begin{array}{l}\text { Monthly } \\
\text { Income }\end{array}$} & Below 20000 & 22 & 44 \\
\hline & & $20000-40000$ & 15 & 30 \\
\hline & & $40000-60000$ & 7 & 14 \\
\hline & & $60000-80000$ & 4 & 118 \\
\hline & & Above 80000 & 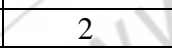 & 4 \\
\hline \multirow{2}{*}{6} & \multirow{2}{*}{ Marital Status } & Married & 27 & 54 \\
\hline & & Unmarried & 23 & 46 \\
\hline \multirow{3}{*}{7} & \multirow{3}{*}{ Family Size } & Small & 12 & 24 \\
\hline & & Medium & 23 & 46 \\
\hline & & Large & 15 & 30 \\
\hline \multirow{3}{*}{8} & \multirow{3}{*}{$\begin{array}{l}\text { Residential } \\
\text { Area }\end{array}$} & Rural & 25 & 50 \\
\hline & & Semi-Urban & 11 & 22 \\
\hline & & Urban & 14 & 28 \\
\hline
\end{tabular}

From Table 1, it is evident that $50 \%$ of the respondents belonged to the age group of $21-30$ years, $52 \%$ of the respondents were male, $30 \%$ of the respondents were graduates, $34 \%$ of the respondents were employees, $44 \%$ of the respondents family monthly income was less than Rs. $20,000,54 \%$ of the respondents were married, $46 \%$ of the respondents belong to medium size family. $50 \%$ of the respondents belong to rural area for taken for this study.

Table 2: Products Possessed By The Respondents In Their

\begin{tabular}{|c|c|c|c|c|}
\hline \multirow{2}{*}{ Products } & No & & Yes & \\
\cline { 2 - 5 } & $\mathrm{N}$ & $\%$ & $\mathrm{~N}$ & $\%$ \\
\hline Mixie & 1 & 2 & 49 & 98 \\
\hline Grinder & 5 & 10 & 45 & 90 \\
\hline Washing Machines & 15 & 30 & 35 & 70 \\
\hline Refrigerator & 13 & 26 & 37 & 74 \\
\hline TV & 1 & 2 & 49 & 98 \\
\hline Laptop/PC & 10 & 20 & 40 & 80 \\
\hline Mobile Phones & 1 & 2 & 49 & 98 \\
\hline Water purifier & 26 & 52 & 24 & 48 \\
\hline Microwave Oven & 39 & 78 & 11 & 22 \\
\hline Air conditioner & 37 & 74 & 13 & 26 \\
\hline
\end{tabular}

Table 2 indicates that $98 \%$ of the respondents own Mixie, TV and Mobile Phones, 90\% of the respondents own Grinder, $80 \%$ of the respondents own Laptop/PC, $74 \%$ of the respondents own Refrigerator, $70 \%$ of the respondents own Washing Machines, $48 \%$ of the respondents own Water purifier, $26 \%$ of the respondents own Air conditioner and the remaining $22 \%$ of the respondents own Microwave oven.

\section{Advertisements Watched in Different Media}

Advertising intends to promote the sales of a product or service and also to inform the masses about its features. It is an effective means of communicating the value of a product or service with people at large. Advertising utilizes different media to reach out to the masses. It uses different types of appeals to connect to consumers spread across the globe. The advertising industry provides a platform for the business entities to spread awareness about the products and services offered by them. Advertising gets to people through different forms of communication. The various types of advertising appeals use different ways to highlight the product features and draw mass attention.

Table 3: Advertisements Watched in Different Media

\begin{tabular}{|c|c|c|c|c|c|c|c|c|c|c|c|c|}
\hline \multirow{2}{*}{ Media } & \multicolumn{1}{|c|}{1} & \multicolumn{2}{|c|}{2} & \multicolumn{3}{|c|}{3} & \multicolumn{2}{|c|}{4} & \multicolumn{3}{|c|}{ Total } \\
\cline { 2 - 13 } & $\mathrm{N}$ & $\%$ & $\mathrm{~N}$ & $\%$ & $\mathrm{~N}$ & $\%$ & $\mathrm{~N}$ & $\%$ & $\mathrm{~N}$ & $\%$ & $\mathrm{~N}$ & $\%$ \\
\hline \multirow{2}{*}{ Print } & 4 & 8 & 1 & 2 & 1 & 2 & 1 & 2 & 1 & 2 & 5 & 10 \\
& & & 1 & 2 & 3 & 6 & 1 & 2 & 1 & 2 & 0 & 0 \\
\hline \multirow{2}{*}{ Radio } & 5 & 1 & 1 & 3 & 1 & 2 & & 1 & 1 & 2 & 5 & 10 \\
\hline Television & 3 & 7 & 5 & 0 & 0 & 0 & & 8 & 1 & 2 & 0 & 0 \\
\hline Hoardings \& & 5 & 0 & 6 & 2 & 4 & 8 & 3 & 6 & 2 & 4 & 5 & 10 \\
Banners & 4 & 8 & 1 & 2 & 1 & 2 & 1 & 2 & 1 & 2 & 5 & 10 \\
\hline $\begin{array}{c}\text { Displays/Exhibi } \\
\text { tions }\end{array}$ & 2 & 4 & 8 & 1 & 1 & 2 & 1 & 3 & 1 & 2 & 5 & 10 \\
\hline
\end{tabular}

From the above table it is clear that 35 respondents have given first rank to television, 15 respondents have given second rank to radio, 13 respondents have considered print as third rank, 17 respondents have marked four to displays/exhibitions and 12 respondents have given rank five to hoardings and banners.

\section{Respondents Influenced by Others Opinion}

People believe another individual to be credible for a variety of reasons, such as perceived experience, attractiveness, knowledge, etc. Those with access to the media may use this access in an attempt to influence the public. An attempt was made to find out if the respondents are influenced by others opinion.

Table 4: Respondents According To Influenced By Others Opinion

\begin{tabular}{|c|c|c|c|}
\hline S. No. & $\begin{array}{c}\text { Influenced by } \\
\text { others opinion }\end{array}$ & No. of Respondents & Percentage \\
\hline 1 & Yes & 48 & 96 \\
\hline 2 & No & 2 & 4 \\
\hline & Total & $\mathbf{5 0}$ & $\mathbf{1 0 0}$ \\
\hline
\end{tabular}

From the above table reveals that $96 \%$ of the respondents were influenced by others opinion about durable goods and the remaining $4 \%$ of the respondents were not influenced by others opinion.

\section{Sources of Influence in making Purchase Decision of Durable Goods}

Peoples opinions or behaviours can be changed as a result of social influences from a multitude of resources and individuals. The following table provides that sources of 


\section{International Journal of Science and Research (IJSR) ISSN (Online): 2319-7064}

Index Copernicus Value (2013): 6.14 | Impact Factor (2015): 6.391

influence in purchase decision of consumer durables.

Table 5: Sources of Influence on Respondents in Respect of Purchase Decision

\begin{tabular}{|c|c|c|c|}
\hline S. No. & Sources of Influence & No. of Respondents & Percentage \\
\hline 1 & Spouse & 5 & 10.42 \\
\hline 2 & Family members & 27 & 56.25 \\
\hline 3 & Friends & 12 & 25 \\
\hline 4 & Relatives & 4 & 8.33 \\
\hline & Total & 48 & 100 \\
\hline
\end{tabular}

Table 5 shows that $56.25 \%$ of the respondents were influenced by the family members, $25 \%$ of the respondents were influenced by the friends, $10.42 \%$ of the respondents were influenced by their spouse, $8.33 \%$ of the respondents were influenced by the relatives. Hence it is concluded that majority of the respondents were influenced by the family members.

\section{Factors influencing the Purchase Decision of consumer Durable goods}

The marketing organization must facilitate the consumers to act on their purchase intention. The organization can use a variety of techniques to achieve this. The relevant internal psychological process that is associated with purchase decision is integration. Once the integration is achieved, the organization can influence the purchase decisions much more easily. The owner of a registered brand personally stands behind the branded product and offers personal guarantee for maintaining the quality and standards of the product. Consumer durable are normally more valued, high priced products and not frequently purchased products. The following table presents the opinion of the respondents about the factors influencing the purchase decision of consumer durable goods.

Table 6:

\begin{tabular}{|c|c|c|c|c|c|c|c|c|c|c|c|c|}
\hline \multirow{2}{*}{ Factors } & \multicolumn{1}{|c|}{ SDA } & \multicolumn{2}{|c|}{ DA } & \multicolumn{2}{c|}{ NN } & \multicolumn{2}{|c|}{ A } & \multicolumn{2}{c|}{ SA } & \multicolumn{2}{c|}{ Total } \\
\cline { 2 - 14 } & $\mathrm{N}$ & $\%$ & $\mathrm{~N}$ & $\%$ & $\mathrm{~N}$ & $\%$ & $\mathrm{~N}$ & $\%$ & $\mathrm{~N}$ & $\%$ & $\mathrm{~N}$ & $\%$ \\
\hline Price & 3 & 6 & 7 & 14 & 8 & 16 & 22 & 44 & 10 & 20 & 50 & 100 \\
\hline Colour & 2 & 4 & 4 & 8 & 10 & 20 & 20 & 40 & 14 & 28 & 50 & 100 \\
\hline Brand Preference & 3 & 6 & 7 & 14 & 12 & 24 & 18 & 36 & 10 & 20 & 50 & 100 \\
\hline Offers / Discounts & 1 & 2 & 8 & 16 & 10 & 20 & 21 & 42 & 10 & 20 & 50 & 100 \\
\hline Technical Features & 2 & 4 & 5 & 25 & 10 & 20 & 20 & 40 & 13 & 26 & 50 & 100 \\
\hline Quality & 2 & 4 & 4 & 8 & 14 & 28 & 22 & 44 & 8 & 16 & 50 & 100 \\
\hline Shape / Size & 3 & 6 & 6 & 12 & 14 & 28 & 17 & 34 & 10 & 20 & 50 & 100 \\
\hline Brand Image & 3 & 6 & 7 & 14 & 8 & 16 & 21 & 42 & 10 & 20 & 50 & 100 \\
\hline Model / Design & 3 & 6 & 5 & 10 & 10 & 20 & 20 & 40 & 12 & 24 & 50 & 100 \\
\hline Celebrity & 1 & 2 & 3 & 6 & 10 & 20 & 18 & 36 & 18 & 36 & 50 & 100 \\
\hline
\end{tabular}

Opinion About The Factors Influencing The Purchase Decision Of Consumer Durable Goods

From the above table it is clear that majority $44 \%$ of the respondents are agreed with the factor of "Price" and "Quality", 42\% of the respondents are agreed with the factor of "Offers/Discounts" and "Brand Image", $40 \%$ of the respondents are agreed with the factor of "Colour", "Technical Features" and "Model / Design". 36\% of the respondents are agreed with the factor of "Brand Preference" and "Celebrity"

\section{Suggestions}

- Demand for consumer durables is more volatile since it moves rapidly or evaporates quickly in relation to business conditions. Marketers separate the current demand for durable goods in terms of replacement old products and expansion of the total stock demand for such goods.

- Consumers prefer high valued consumer durables of well established brands. The marketers and manufacturers of the consumer durables must try to convert the brand consciousness into brand loyalty for their well established brands. The consumer behaviour in this direction should properly be exploited by the manufacturers and dealers to maximize their sales.

- The buyers of consumer durables have largely shown their preference to make extensive enquiry from the dealers of different brands of the products. This trait should be emulated by all the buyers in order to avoid post purchase dissatisfaction about the quality and performance of the products.

- Concessions in the price, price reductions, discounts sell, gifts, etc., have become common practices. The buyers of consumer durables should try to avail of these benefits, whenever they are available however, the buyers of such goods should not be lured mere by consciousness without considering the quality and performance aspects of these higher value products.

- The buyers of the consumer durables should insist that all the technical information are revealed on the use of durable products to enable them to use the products without any technical fault leading to frequent repairs, free servicing of the durables by dealers during the guarantee period insisted upon the buyers.

\section{Conclusion}

The market for consumer durables is becoming more competitive now a days. Therefore, the producer of durable products should understand consumer interest much to find higher sale of their products. Marketers communicate with consumers and try to convince through every possible media. Highly inevitable to produce goods as preferred by the customer, as he is the kingpin around whom the entire marketing activity revolves. Thus, a marketer who understands the behaviour of the consumers and plan his marketing strategies to suit the needs and aspirations of the target market will definitely have an advantage over his competitors.

\section{References}

[1] Losarwar. S.G., "Consumer Behaviour towards Durable Products -A Study with reference to Marathwada Region”, Indian Journal of Marketing, November 2002, pp.6-9.

[2] Ruche Trehan and Harman Deep Singh, "A Comparative Study on Urban and rural Consumer ", Indian Journal of Marketing, Vol. XXXIII, No.8, August 2003, pp.7-11.

[3] Dr. Hitesh D. Vyas, "Consumer Purchase of Consumer Durables: A Factorial Study", InternationalJournal of 


\section{International Journal of Science and Research (IJSR) \\ ISSN (Online): 2319-7064}

Index Copernicus Value (2013): 6.14 | Impact Factor (2015): 6.391

Management \& Strategy, July-December, 2010, Vol.1, No.1, pp. 1- 8/13.

[4] Consumer Behaviour By-Ramanuj Majumdar

[5] Consumer Behaviour and Marketing Communication By Kazmi

[6] Venkateswara. M. and Reddy. B., "Marketing of TV sets

- A Study of External and Internal Influence on

Consumer Behaviour", Indian Journal of Marketing, Vol.27 (8): 20-24, August 1997. 